\title{
Microsatellite primer development for the seagrass Zostera nigricaulis (Zosteraceae)
}

Timothy M. Smith, Paul H. York, Annalise M. Stanley, Peter I. Macreadie, Michael J. Keough, D. Jeff Ross and Craig D. H. Sherman

T. M. Smith, P. H. York, A. M. Stanley, C. D. H. Sherman,

School of Life and Environmental Science, Centre of Integrative Ecology,

Deakin University, Pigdons Rd, Waurn Ponds, VIC, 3217, Australia

e-mail: tim.smith@deakin.edu.au

P. I. Macreadie

Plant Functional Biology and Climate Change Cluster (C3), School of the Environment, University of Technology Sydney, Broadway NSW 2007, Australia

M. J. Keough

Department of Zoology, University of Melbourne, Victoria 3010 Australia

D. J. Ross

Institute for Marine and Antarctic Studies, University of Tasmania, Taroona TAS 7053, Australia 


\begin{abstract}
Seagrasses are marine angiosperms with a worldwide distribution that form conspicous beds in nearshore habitats. Despite being universally recogised as a foundation species that performs a number of important ecosystems functions (incl. sediment stabilisation, facilitation of biodiversity, nurtient cycling and carbon sequestration), global seagrass habitats are in decline. Resilience - the ability to recover from disturbance without swithing to an alternative state - is paramount to the maintenance and persistence of seagrass habitats. Genetic diversity is a key component of seagrass resilience and contributes to an understanding of population structure, connectivity between populations, and reproductive strategies. Microsatellite primers were developed to investigate the resilience of the seagrass Zostera nigricaulis, which dominates subtidal habitats in the bays of south-eastern Australia. We also tested for cross-amplification of markers between Z. nigricaulis and previously developed markers for the sympatric species Z. muelleri to assess their applicability for use in assessing patterns of genetic diversity, population structure, and mating system. Using next-generation sequencing we isolated 11 novel microsatellite loci for Z. nigricaulis, 8 of which were polymorphic for the samples tested. Allelic diversity ranged from 1 to 8 . None of the primer pairs developed for Z. nigricaulis cross-amplified in Z. muelleri; but 14 of 24 primer pairs previously developed for Z. muelleri amplified clearly in Z. nigricaulis samples with 6 of these showing polymorphism. The results demonstrate the applicability of the Z. nigricaulis microsatellite primers for use in the study of population genetics and limited cross-amplification with Z. muelleri.
\end{abstract}

Key words: Zostera nigricaulis; microsatellite markers; cross-amplification; genetic structure; seagrass 
Seagrasses are important foundation species that occupy shallow estuarine and coastal waters and provide a variety of important ecosystem services with substantial economic value (e.g. facilitation of biodiversity; fisheries production; sediment stabilisation; nutrient cycling \& carbon sequestration, Short et al. 2011). Seagrasses are under constant disturbance pressure from both natural and anthropogenic causes and have been declining globally at ever increasing rates (Waycott et al. 2009). The resilience of seagrasses depends on their ability to either withstand these external stressors, or recover from losses through both sexual and asexual reproductive strategies.

Zostera species are among the most important, widely distributed and, therefore, well-studied seagrass species globally. Zostera nigricaulis Kuo (Zosteracaea), has a native range extending from Western Australia around the southern coast of Australia to central New South Wales (Kuo 2005; Les et al. 2002). Zostera nigricaulis is distinguished from other Zostera species by the presence of erect, dark brown stems and is the dominant subtidal species found in Port Phillip Bay, Victoria, Australia (Kuo 2005). Currently there are no published genetic markers for Z. nigricaulis, hampering efforts to understand Z. nigricaulis population genetics. Here we developed a set of microsatellite markers to examine key population parameters; including: genetic structure, diversity, clonal structure, and patterns of connectivity in Z. nigricaulis populations from south-eastern Australia.

Approximately $10 \mu \mathrm{g}$ of genomic DNA from fresh leaf tissue from a single individual of Zostera nigricaulis collected from Port Phillip Bay, Victoria, Australia using DNeasy plant kits (QIAGEN), following the manufacturers instructions. We developed microsatellites following the methodology of Sherman et al. (2012) and Gardner et al. (2011). Briefly, we sequenced one-eighth of a plate using the GS-FLX 454 platform (Roche, Germany), providing 121,156 sequenced reads. A total of 480 unique sequence reads possessing microsatellite motifs were identified using the software QDD v 1.3 (Meglecz et al. 2010). Primer pairs were designed using default settings on Primer3 for 24 of the fragments (Rozen and Skaletsky 2000). Multiplexes consisting of four loci were designed where forward primers had a fluorescent dye associated tag added (FAM-

GCCTCCCTCGCGCCA; NED-GCCTTGCCAGCCCGC; VIC-CAGGACCAGGCTACCGTG; PETCGGAGAGCCGAGAGGTG) (Blacket et al. 2012).

To test loci for levels of polymorphism, we screened six individuals collected from Port Phillip Bay, Victoria, Australia. DNA extraction followed the method reported above. Polymerase chain reactions (PCR) were 
conducted in $11 \mu \mathrm{L}$ volumes containing; 10 ng of genomic DNA; $5 \mu \mathrm{L}$ PCR Master Mix (Qiagen, USA) and 4 $\mu \mathrm{L}$ primer multiplex $(0.26 \mu \mathrm{M}$ of each forward primer and fluorescent dye, $0.13 \mu \mathrm{M}$ of reverse primer). PCR products were amplified using a touchdown programme; initial hot start at $94^{\circ} \mathrm{C}$ for $15 \mathrm{~min}$; five cycles of $94^{\circ} \mathrm{C}$ for $45 \mathrm{~s}, 65^{\circ} \mathrm{C}$ for $45 \mathrm{~s}, 72^{\circ} \mathrm{C}$ for $45 \mathrm{~s}$; five cycles of $94^{\circ} \mathrm{C}$ for $45 \mathrm{~s}, 60^{\circ} \mathrm{C}$ for $45 \mathrm{~s}, 72^{\circ} \mathrm{C}$ for $45 \mathrm{~s} ; 10$ cycles of $94^{\circ} \mathrm{C}$ for $45 \mathrm{~s}, 57^{\circ} \mathrm{C}$ for $45 \mathrm{~s}, 72^{\circ} \mathrm{C}$ for $45 \mathrm{~s} ; 20$ cycles of $94^{\circ} \mathrm{C}$ for $45 \mathrm{~s}, 55^{\circ} \mathrm{C}$ for $45 \mathrm{~s}, 72^{\circ} \mathrm{C}$ for $45 \mathrm{~s}$; final elongation at $72^{\circ} \mathrm{C}$ for $15 \mathrm{~min}$. PCR amplicons were electrophoresed using an ABI 3130xl Genetic Analyzer, incorporating LIZ 500 (-250) size standard (Applied Biosystems). Alleles were scored using GeneMapper, v3.7 (Applied Biosystems). Population genetic statistics were calculated with GENEPOP on the web (Raymond and Rousset 1995) and GENALEX (V6.41) (Peakall and Smouse 2006). We tested the statistical power of the marker system to identify different clones by calculating the probability of identity, $\mathrm{P}_{I D}$, for increasing locus combinations (Waits et al. 2001) using the program GENALEX (V6.41) (Peakall and Smouse 2006). This identification estimator calculates the probability that two individuals drawn at random from a population will have the same genotype at multiple loci and is used to assess the statistical confidence of the marker system for individual identification. $\mathrm{P}_{I D}$ was calculated for each locus and then multiplied across loci to give an overall $\mathrm{P}_{I D}$ (Waits et al. 2001).

Eleven microsatellite primer pairs (Table 1) amplified clearly and consistently; of these 8 were polymorphic within the seagrasses sampled. Overall we detected moderate levels of polymorphism across the variable loci with the number of alleles per locus ranging from 2 to 8 and a mean of 3.50 alleles per locus. Estimates of unbiased expected heterozygosity ranged from 0.28 to 0.86 , with a mean of 0.53 , while observed heterozygosity varied from 0.00 to 0.80 , with a mean of 0.61 (Table 2). Three loci showed significant deviations from HardyWeinberg equilibrium, however, none of these remained significant after sequential Bonferroni correction for multiple tests. We also report details of three monomorphic primer pairs (ZosVic 49, ZosVic 53 and ZosVic 64), as these loci may prove useful for population genetic studies of other widely geographically isolated populations despite the lack of variability in the sampled population. All individuals displayed a unique multi-locus genotype and the combined probability of identity across all variable loci was low $\left(\mathrm{P}_{I D}=5.79 \times 10^{-06}\right)$, suggesting that these loci have a high level of power in detecting unique genotypes in this highly clonal species.

We also tested the ability of the primers developed in this study to cross-amplify in the closely related, cooccurring seagrass Z. muelleri Irmisch ex Asch. using samples collected from Lake Macquarie, New South Wales. Similarly, we tested the cross-amplification of recently developed Z. muelleri primers (Sherman et al. 
2012) in Z. nigricaulis samples from this study. DNA was extracted and the loci genotyped for individuals and statistics generated following the protocols described above. Our results showed that none of the primer pairs developed for Z. nigricaulis amplified in Z. muelleri samples (Table 2). Of the 24 primer pairs developed for Z. muelleri, fourteen amplified clearly in Z. nigricaulis samples, but only six of these were polymorphic (Table 2). Levels of polymorphism across the six loci that cross-amplified were low ranging between 2 and 4 alleles with a mean of 2.5 alleles per locus. Low levels of cross amplification between primer pairs developed for each species supports the distinction of Z. nigricaulis and Z. muelleri as separate species (Les et al. 2002). The markers developed here will be a powerful tool for assessing patterns of population connectivity, levels of genetic diversity, and an understanding of the relative importance of asexual versus sexual reproduction to population persistence in this ecologically important species.

\section{Acknowledgments}

The Authors would like to thank A. Hirst, N. Hutchinson, C. White and D. Hatton for assistance with specimen collection. This study was financially supported by a research grant from the Victorian Department of Sustainability and Environment: 'Seagrass resilience in Port Phillip Bay: developing better predictions of how seagrasses respond to environmental change'.

\section{References}

Blacket MJ, Robin C, Good RT, Lee SF, Miller AD (2012) Universal primers for fluorescent labelling of PCR fragments-an efficient and cost-effective approach to genotyping by fluorescence. Mol Ecol Resour 12 (3):456-463. doi:10.1111/j.1755-0998.2011.03104.x

Gardner MG, Fitch AJ, Bertozzi T, Lowe AJ (2011) Rise of the machines - recommendations for ecologists when using next generation sequencing for microsatellite development. Mol Ecol Resour 11 (6):1093-1101. doi:10.1111/j.1755-0998.2011.03037.x

Kuo J (2005) A revision of the genus Heterozostera (Zosteraceae). Aquat Bot 81 (2):97-140. doi:10.1016/j.aquabot.2004.10.005

Les DH, Moody ML, Jacobs SWL, Bayer RJ (2002) Systematics of seagrasses (Zosteraceae) in Australia and New Zealand. Systematic Botany 27 (3):468-484 
Meglecz E, Costedoat C, Dubut V, Gilles A, Malausa T, Pech N, Martin J-F (2010) QDD: a userfriendly program to select microsatellite markers and design primers from large sequencing projects. Bioinformatics 26 (3):403-404. doi:10.1093/bioinformatics/btp670

Peakall R, Smouse PE (2006) GENALEX 6: genetic analysis in Excel. Population genetic software for teaching and research. Molecular Ecology Notes 6 (1):288-295. doi:10.1111/j.14718286.2005.01155.x

Raymond M, Rousset F (1995) GENPOP (Version 1.2): population genetics software for exact tests and ecumenicism. Journal of Heredity 86 (3):248-249

Rozen S, Skaletsky H (2000) Primer3 on the WWW for general users and for biologist programmers. Methods in molecular biology (Clifton, NJ) 132:365-386

Sherman C, Stanley A, Keough M, Gardner M, Macreadie P (2012) Development of twenty-three novel microsatellite markers for the seagrass, Zostera muelleri from Australia. Conservation Genetics Resources 4 (3):689-693. doi:10.1007/s12686-012-9623-8

Short FT, Polidoro B, Livingstone SR, Carpenter KE, Bandeira S, Bujang JS, Calumpong HP, Curruthers TJB, Coles RG, Dennison WC, Erftemeijer PLA, Fortes MD, Freeman AS, Japtap TG, Kamal AHM, Kendrick GA, Kenworth WJ, La Nafie YA, Nasution IM, Orth RJ, Prathep A, Sanciangco JC, van Tussenbroek B, Vergara SG, Waycott M, Zieman JC (2011) Extinction risk assessment of the world's seagrass species. Biological Conservation 144:1961-1971

Waits LP, Luikart G, Taberlet P (2001) Estimating the probability of identity among genotypes in natural populations: cautions and guidelines. Mol Ecol 10 (1):249-256. doi:10.1046/j.1365294X.2001.01185.x

Waycott M, Duarte CM, Carruthers TJB, Orth RJ, Dennison WC, Olyarnik S, Calladine A, Fourqurean JW, Heck KL, Hughes AR, Kendrick GA, Kenworthy WJ, Short FT, Williams SL (2009) Accelerating loss of seagrasses across the globe threatens coastal ecosystems. Proceedings of the National Academy of Sciences of the United States of America 106 (30):12377-12381. doi:10.1073/pnas.0905620106 
Tables

TABLE 1. Microsatellite markers developed for 11 loci in the seagrass Zostera nigricaulis. $N=$ Number of individuals that amplified. $A=$ Number of alleles. Product size range including the associated fluorescent dye tag (FAM-GCCTCCCTCGCGCCA; NED-GCCTTGCCAGCCCGC; VIC-CAGGACCAGGCTACCGTG; PET(GGAGAGCCGAGAGGTG)(Blacket et al. 2012)

\begin{tabular}{|c|c|c|c|c|c|c|c|}
\hline Locus & $\begin{array}{c}\text { Genbank Acc. } \\
\text { No. }\end{array}$ & Primer sequence $\left(5^{\prime}-3^{\prime}\right)$ & Motif & $\begin{array}{c}\text { Fluorescent } \\
\text { tag }\end{array}$ & $\begin{array}{l}\text { Size } \\
\text { range }\end{array}$ & $N$ & $A$ \\
\hline \multirow[t]{2}{*}{ ZosVIC49 } & JQ236670 & F: AAAGACATGTTCGAGAAACCC & AT & FAM & 157 & 6 & 1 \\
\hline & & R: CGCATATGTGATACGCATAAACC & & & & & \\
\hline \multirow[t]{2}{*}{ ZosVIC55 } & JQ236673 & F: GTGTCAAACTTGCACAACTTCC & $\mathrm{CT}$ & VIC & 194-206 & 6 & 3 \\
\hline & & R: AAAGGTGGGCCTCAGTGTC & & & & & \\
\hline \multirow[t]{2}{*}{ ZosVIC50 } & JQ236671 & F: TCAGCCAAGTATGAGGTGGTC & AT & VIC & $163-167$ & 6 & 2 \\
\hline & & R: GCGAGGCTTGCTTTAGTAGC & & & & & \\
\hline \multirow[t]{2}{*}{ ZosVIC70a } & JQ236678 & F: TCAGCCGGAGGAGAATTGG & CATT & VIC & 201-208 & 5 & 2 \\
\hline & & R: TGACGGAGATGAAGCCACC & & & & & \\
\hline \multirow[t]{2}{*}{ ZosVIC70b } & JQ236678 & F: TCAGCCGGAGGAGAATTGG & CATT & VIC & $215-258$ & 5 & 8 \\
\hline & & R: TGACGGAGATGAAGCCACC & & & & & \\
\hline \multirow[t]{2}{*}{ ZosVIC60 } & JQ236675 & F: ATCCTCTGTTGTGCCCGTC & AT & FAM & $167-203$ & 6 & 2 \\
\hline & & R: GCTGCTATCATTGGTGGCTATG & & & & & \\
\hline \multirow[t]{2}{*}{ ZosVIC69 } & JQ236677 & F: TGGTTGAGCAATGAGATTCGG & ATCC & FAM & $160-180$ & 6 & 4 \\
\hline & & R: TCCACGATGAGTTGTTCTCAAG & & & & & \\
\hline \multirow[t]{2}{*}{ ZosVIC64 } & JQ236676 & F: ACCTGAGATTTCACTTGATCCTG & AT & PET & 204 & 5 & 1 \\
\hline & & R: TCTGGAGGTTTGATCTTCCC & & & & & \\
\hline \multirow[t]{2}{*}{ ZosVIC53 } & JQ236672 & F: TCGAAATGTCGCTTGATGCC & GT & PET & 173 & 3 & 1 \\
\hline & & R: ACTAAGTTGTTGCCGACTTGAC & & & & & \\
\hline \multirow[t]{2}{*}{ ZosVIC59 } & JQ236674 & F: AGACCCTTATTGGGCTGGAG & AT & NED & $196-216$ & 6 & 2 \\
\hline & & R: AACGAGGTTTTGACCTTGCC & & & & & \\
\hline \multirow[t]{2}{*}{ ZosVIC71 } & JQ236679 & F: TTGCAGTCTTGACGAGAAAC & AGTT & VIC & $343-379$ & 5 & 5 \\
\hline & & R: TGCTAGTCTCTGCCGAATG & & & & & \\
\hline
\end{tabular}


TABLE 2. Results of primer screening of Zostera nigricaulis from Port Phillip Bay and Z. muelleri from Lake Macquarie. $N=$ Number of individuals that amplified, $A=$ Number of alleles, $\mathrm{H}_{\mathrm{O}}=$ Observed heterozygosity, $\mathrm{UH}_{\mathrm{E}}=$ Unbiased expected heterozygosity

\begin{tabular}{|c|c|c|c|c|c|c|c|c|}
\hline \multirow[b]{2}{*}{ Loci } & \multicolumn{4}{|c|}{$\begin{array}{l}\text { Zostera nigricaulis } \\
\text { Port Phillip Bay }(n=6)\end{array}$} & \multicolumn{4}{|c|}{$\begin{array}{c}\text { Zostera muelleri } \\
\text { Lake Macquarie }(n=8)\end{array}$} \\
\hline & $N$ & A & $\mathrm{H}_{\mathrm{O}}$ & $\mathrm{UH}_{\mathrm{E}}$ & $N$ & $\mathrm{~A}$ & $\mathrm{H}_{\mathrm{O}}$ & $\mathrm{UH}_{\mathrm{E}}$ \\
\hline ZosVIC49 & 6 & 1 & 0.000 & 0.000 & 0 & 0 & 0.000 & 0.000 \\
\hline ZosVIC55 & 6 & 3 & 0.667 & 0.612 & 0 & 0 & 0.000 & 0.000 \\
\hline ZosVIC50 & 6 & 2 & 0.000 & 0.303 & 0 & 0 & 0.000 & 0.000 \\
\hline ZosVIC70a & 5 & 2 & 1.000 & 0.556 & 0 & 0 & 0.000 & 0.000 \\
\hline ZosVIC70b & 5 & 8 & 0.800 & 0.956 & 0 & 0 & 0.000 & 0.000 \\
\hline ZosVIC60 & 6 & 2 & 0.833 & 0.530 & 0 & 0 & 0.000 & 0.000 \\
\hline ZosVIC69 & 6 & 4 & 0.333 & 0.697 & 0 & 0 & 0.000 & 0.000 \\
\hline ZosVIC64 & 5 & 1 & 0.000 & 0.000 & 0 & 0 & 0.000 & 0.000 \\
\hline ZosVIC53 & 3 & 1 & 0.000 & 0.000 & 0 & 0 & 0.000 & 0.000 \\
\hline ZosVIC59 & 6 & 2 & 0.833 & 0.530 & 0 & 0 & 0.000 & 0.000 \\
\hline ZosVIC71 & 5 & 5 & 0.200 & 0.822 & 0 & 0 & 0.000 & 0.000 \\
\hline ZosNSW02 & 1 & 1 & 0.000 & 0.000 & 8 & 3 & 0.375 & 0.575 \\
\hline ZosNSW13 & 3 & 1 & 0.000 & 0.000 & 6 & 2 & 0.500 & 0.409 \\
\hline ZosNSW15 & 0 & 0 & 0.000 & 0.000 & 7 & 3 & 0.571 & 0.538 \\
\hline ZosNSW17 & 1 & 1 & 0.000 & 0.000 & 7 & 3 & 0.429 & 0.692 \\
\hline ZosNSW18 & 0 & 0 & 0.000 & 0.000 & 7 & 3 & 0.429 & 0.385 \\
\hline ZosNSW19 & 0 & 0 & 0.000 & 0.000 & 7 & 5 & 0.429 & 0.593 \\
\hline ZosNSW20 & 5 & 1 & 0.000 & 0.000 & 7 & 8 & 1.000 & 0.912 \\
\hline ZosNSW23 & 5 & 2 & 1.000 & 0.556 & 7 & 2 & 0.429 & 0.363 \\
\hline ZosNSW25 & 4 & 3 & 0.250 & 0.464 & 8 & 3 & 0.000 & 0.633 \\
\hline ZosNSW27 & 6 & 2 & 1.000 & 0.545 & 8 & 1 & 0.000 & 0.000 \\
\hline ZosNSW28 & 3 & 2 & 0.333 & 0.333 & 8 & 2 & 0.500 & 0.400 \\
\hline ZosNSW29 & 5 & 1 & 0.000 & 0.000 & 8 & 2 & 0.500 & 0.700 \\
\hline ZosNSW34 & 6 & 2 & 1.000 & 0.545 & 8 & 2 & 0.500 & 0.400 \\
\hline ZosNSW35 & 0 & 0 & 0.000 & 0.000 & 8 & 1 & 0.000 & 0.000 \\
\hline ZosNSW36 & 3 & 4 & 0.333 & 0.867 & 5 & 3 & 0.200 & 0.644 \\
\hline ZosNSW38 & 5 & 1 & 0.000 & 0.000 & 8 & 3 & 0.750 & 0.700 \\
\hline ZosNSW40 & 0 & 0 & 0.000 & 0.000 & 8 & 2 & 0.000 & 0.233 \\
\hline ZosNSW41 & 0 & 0 & 0.000 & 0.000 & 4 & 1 & 0.000 & 0.000 \\
\hline ZosNSW42 & 0 & 0 & 0.000 & 0.000 & 8 & 2 & 0.000 & 0.400 \\
\hline ZosNSW43 & 2 & 1 & 0.000 & 0.000 & 8 & 2 & 0.500 & 0.400 \\
\hline ZosNSW44 & 0 & 0 & 0.000 & 0.000 & 8 & 1 & 0.000 & 0.000 \\
\hline ZosNSW45 & 6 & 1 & 0.000 & 0.000 & 8 & 4 & 0.625 & 0.725 \\
\hline ZosNSW46 & 0 & 0 & 0.000 & 0.000 & 8 & 10 & 1.000 & 0.900 \\
\hline ZosNSW47 & 0 & 0 & 0.000 & 0.000 & 8 & 3 & 0.000 & 0.633 \\
\hline
\end{tabular}




\section{University Library}

\section{- M M N E R VA A gateway to Melbourne's research publications}

Minerva Access is the Institutional Repository of The University of Melbourne

Author/s:

Smith, TM;York, PH;Stanley, AM;Macreadie, Pl;Keough, MJ;Ross, DJ;Sherman, CDH

Title:

Microsatellite primer development for the seagrass Zostera nigricaulis (Zosteraceae)

Date:

2013-09-01

Citation:

Smith, T. M., York, P. H., Stanley, A. M., Macreadie, P. I., Keough, M. J., Ross, D. J. \& Sherman, C. D. H. (2013). Microsatellite primer development for the seagrass Zostera nigricaulis (Zosteraceae). CONSERVATION GENETICS RESOURCES, 5 (3), pp.607-610. https://doi.org/10.1007/s12686-013-9862-3.

Persistent Link:

http://hdl.handle.net/11343/282904 